\title{
Single nucleotide polymorphisms in CAPN and leptin genes associated with meat color and tenderness in Nellore cattle
}

\author{
L.F.B. Pinto ${ }^{1}$, J.B.S. Ferraz ${ }^{2}$, V.B. Pedrosa ${ }^{2}$, J.P. Eler ${ }^{2}$, F.V. Meirelles ${ }^{2}$, \\ M.N. Bonin ${ }^{2}$, F.M. Rezende ${ }^{2}$, M.E. Carvalho ${ }^{2}$, D.C. Cucco ${ }^{2}$ and R.C.G. Silva ${ }^{3}$ \\ ${ }^{1}$ Departamento de Produção Animal, \\ Escola de Medicina Veterinária e Zootecnia, \\ Universidade Federal da Bahia, Salvador, BA, Brasil \\ ${ }^{2}$ Grupo de Melhoramento Animal e Biotecnologia, \\ Departamento de Ciências Básicas, \\ Faculdade de Zootecnia e Engenharia de Alimentos, \\ Universidade de São Paulo, Pirassununga, SP, Brasil \\ ${ }^{3}$ Merial Saúde Animal Ltda., Campinas, SP, Brasil \\ Corresponding author: J.B.S. Ferraz \\ E-mail: jbferraz@usp.br
}

Genet. Mol. Res. 10 (3): 2057-2064 (2011)

Received January 14, 2011

Accepted May 19, 2011

Published September 15, 2011

DOI http://dx.doi.org/10.4238/vol10-3gmr1263

ABSTRACT. We analyzed single nucleotide polymorphisms in calpain, leptin, leptin receptor, and growth hormone receptor genes and their association with color, drip and cooking losses of longissimus muscle at 7, 14 and 21 days postmortem in 638 purebred Nellore bulls slaughtered between 22 and 26 months of age. Meat samples were vacuum-packed and aged at $4^{\circ} \mathrm{C}$. The single nucleotide polymorphisms T945M, GHR2, E2FB, and CAPN4751 were evaluated. All genotypic classes were observed; however, the T/T genotype of T945M and E2FB was found at a low frequency. A significant association of E2FB with drip loss (a measure of water-holding capacity) was detected at seven days of meat aging. CAPN4751 had an additive effect on red and yellow color intensities. The T allele of CAPN4751 
was found to be positively associated with improved meat color, but not with meat tenderness, differing from a previous report indicating that it is associated with meat tenderness. We conclude that the potential for use of CAPN4751 as a marker for these meat quality traits requires further research.

Key words: Beef; Bovine; Genome; Livestock; Molecular markers; SNP

\section{INTRODUCTION}

Several traits can be used for analyzing meat quality in cattle, but color is the main factor observed by consumers when purchasing the product, according to Mancini and Hunt (2005), while Viljoen et al. (2002) report that the intensity of the red color has a large effect on consumers. Environmental factors such as stress, diet, husbandry system, and slaughter age have an effect on the meat color, but few studies mention the influence of genetic factors in cattle. Reardon et al. (2010) reported single nucleotide polymorphisms (SNPs) for color trait in Bos taurus cattle.

Drip and cooking losses may reduce muscle weight by 1 to $3 \%$, according to HuffLonergan and Lonergan (2005). Several factors, such as $\mathrm{pH}$, ionic potential and oxidation of muscle fibers, affect water-holding capacity, but little is known about the genetic control of these losses. In pigs, PSE (pale, soft, and exudative) meat is influenced by a recessive mutation in the ryanodine receptor gene, known as the halothane gene, and molecular markers on this gene have improved the selection process. Water loss during cooking is also important, since it has a great effect on the final product quality, affecting mostly the juiciness and tenderness. Although genetic factors are also obscure, Reardon et al. (2010) reported an association of the PRKAG3 SNP with cooking loss in longissimus muscle $(\mathrm{P}<0.05)$.

For cattle breeding purposes, meat color, drip and cooking losses are highly complex traits because they cannot be measured in vivo. However, information obtained from molecular markers can improve the genetic selection. Thus, this study aims to detect associations between molecular markers and meat quality traits in Nellore cattle.

\section{MATERIAL AND METHODS}

\section{Population}

Phenotypic and genotypic information of 638 non-castrated Nellore bulls were used. All animals were progenies of bulls from Agropecuária CFM Ltda. that were selected for production and reproduction traits. The animals were raised under pasture conditions until 18 to 22 months of age and then fed on feedlots until slaughter, between 22 and 26 months of age, in 2006. The slaughter occurred on six different days, always in the mornings, and after, approximately $16 \mathrm{~h}$ of fasting. Every animal was perfectly identified for measurements and sample collection.

\section{Phenotypic traits}

After slaughter, the carcasses were sawed longitudinally down the middle. Then, they were chilled for $24 \mathrm{~h}$ at $2^{\circ} \pm 1^{\circ} \mathrm{C}$. After this period, the $\mathrm{pH}$ was evaluated and three samples of the longissimus muscle were removed between the $12 \mathrm{nd}$ and $13 \mathrm{rd}$ ribs, always on the same side of the 
carcass. Samples were vacuum-packed and aged at $4^{\circ} \pm 1^{\circ} \mathrm{C}$ for 7,14 and 21 days postmortem. No samples were frozen. All meat samples were measured for drip and cooking losses, according to the American Meat Science Association - AMSA (1995) guidelines, while luminosity $\left(L^{*}\right)$, red $\left(a^{*}\right)$ and yellow $\left(b^{*}\right)$ colors were obtained with a Hunter Lab MiniScan XE, with a D65 light source and a $10^{\circ}$ angle of measurement. $L^{*}, a^{*}$ and $b^{*}$ followed the CIELab scale, where $L^{*}$ is associated with luminosity, $a^{*}$ with the colors from green to red and $b^{*}$ with the colors from blue to yellow.

\section{Genotyping and molecular markers}

The calpain gene (CAPN1) (GenBank accession No. AF248054) is located on chromosome 2. In this gene, the SNP CAPN4751, which is a silent mutation located in intron 17 (base 6545) of CAPN1 and corresponds to the substitution of cytosine/thymine (C/T) according to White et al. (2005), was used. The leptin receptor gene (GenBank accession No. AB199589) is located on chromosome 3. In that gene, the SNP T945M, which is a cytosine to thymine substitution at base 115 that results in a substitution of the amino acid threonine with methionine at residue 945 of leptin (Liefers et al., 2005), was used. The leptin gene (GenBank accession No. AY138588) is located on chromosome 4 and its SNP E2FB, which is a mutation located in exon 2, base 305, a cytosine (C) to thymine ( $\mathrm{T}$ ) transition that encoded an amino acid change of an arginine to a cysteine according to Buchanan et al. (2002), was used. The growth hormone receptor gene (GHR, GenBank accession No. AF044258) is located on chromosome 20, and one of its SNP was used. The GHR2 is a mutation located on bovine chromosome 20 in the position 300 (intron 04) of the GHR gene.

DNA samples were obtained from blood or hair follicles. Genotypes were obtained by

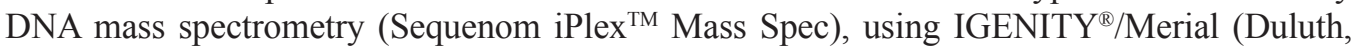
USA) licensed laboratories. Merial is the company that holds the rights of use to those markers. Polymerase chain reactions (PCRs) were carried out with $120 \mathrm{ng}$ DNA, diluted in $25 \mu \mathrm{L}$ containing $0.2 \mu \mathrm{M}$ of each dNTP, $0.5 \mathrm{U}$ Taq DNA polymerase and $0.2 \mu \mathrm{M}$ of each oligonucleotide primer. A total of 32 cycles of $1 \mathrm{~min}$ at $94^{\circ} \mathrm{C}, 30 \mathrm{~s}$ at $58^{\circ} \mathrm{C}$ and $1 \mathrm{~min}$ at $72^{\circ} \mathrm{C}$ were used.

\section{Statistical analysis}

A descriptive statistical analysis was performed to estimate the mean, minimum, maximum, standard deviation, and coefficient of variation, using the MEANS procedure of the Statistical Analysis System software (SAS, 2004). The GLM procedure was used for testing the contemporary group effect obtained for date of slaughter and for testing the effects of the covariates: temperature of the meat at evaluation of $L^{*}, a^{*}$ and $b^{*}$ and $\mathrm{pH}$ $24 \mathrm{~h}$ after slaughter. The effect of maturation time was tested by ANOVA and all groups were compared by the Tukey test at a significance level of 5\%. The associations between SNP markers and phenotypic traits were evaluated with the QXPAK software according to Pérez-Enciso and Misztal (2004). We conducted a likelihood ratio test (LRT) between the reduced models (Equation 1):

$$
y_{i j}=\mu+G C_{i}+\alpha_{i j} T+\delta_{i j} p H+e_{i j} \quad \text { (Equation 1) }
$$

where $Y_{i j}$ is the phenotypic value; $\mu$ is the global mean of the trait; $G C_{i}$ is the fixed effect of the contemporary group obtained from the date of slaughter; $\alpha_{i j}$ is the coefficient associated with the covariate temperature $(\mathrm{T})$ of meat when color was measured; $\delta_{i j}$ is the coefficient associated with covariate 
$\mathrm{pH}$ measured $24 \mathrm{~h}$ after slaughter, and $e_{i i}$ is the residual random effect. To test the additive and dominance effect, the full model (Equation 2) was used, which included primarily the additive effect,

$$
y_{i j}=\mu+G C_{i}+\alpha_{i j} T+\delta_{i j} p H+\beta_{i j} A+e_{i j}
$$

(Equation 2)

when this model was significant, it included the dominance effect as in the model of Equation 3

$$
Y_{i j}=\mu+G C_{i}+\alpha_{i j} T+\delta_{i j} p H+\beta_{i j} A+\tau_{i j} D+e_{i j}
$$

where new terms are: the additive effect $(A)$ associated with the coefficient $\beta_{i j}$ and the dominance effect $(D)$ associated with the coefficient $\tau_{i j^{*}}$. The covariate meat temperature was significant only for $L^{*}$ and $b^{*}$ at 14th and 21st days postmortem aging, so it was not suitable for other traits.

Gene and genotypic frequencies were estimated with the FREQ procedure of the Statistical Analysis System software (SAS, 2004).

\section{RESULTS AND DISCUSSION}

\section{Descriptive analysis}

The mean values of drip loss percentiles ranged from 2.83 to $4.58 \%$, i.e., an increase from the 7 th to 21 st day (Table 1). This was expected due to the modification in cell membranes over the course of the ageing process and these values are similar to those described by Chambaz et al. (2003) in Angus (2.5\%) and Limousin (4.85\%) cattle. The cooking losses were higher than drip losses, ranging from $10.7 \%$ at the 14 th and 21 st days of aging to $12.04 \%$ at 7 days of aging. There was no difference between cooking loss at the 7th and 14th days of aging, but they were different compared to cooking loss on the 21 st day $(\mathrm{P}<0.01)$. The mean values in the present study were lower than the mean values found by Chambaz et al. (2003) in Limousin (14.1\%), Charolais (15.8\%), Simmental (17.01\%), and Angus (20.6\%) cattle. However, Chambaz et al. (2003) used

\begin{tabular}{|c|c|c|c|c|c|c|}
\hline Trait & $\mathrm{N}$ & Mean & SD & Minimum & Maximum & $\mathrm{CV}$ \\
\hline $\mathrm{pH} 24$ & 467 & 5.87 & 0.40 & 5.00 & 6.99 & 6.85 \\
\hline DL7 & 419 & $2.83^{\mathrm{a}}$ & 1.30 & 0.18 & 7.11 & 46.05 \\
\hline DL14 & 430 & $3.70^{\mathrm{b}}$ & 1.58 & 0.41 & 8.89 & 42.60 \\
\hline DL21 & 424 & $4.58^{\mathrm{c}}$ & 1.63 & 0.74 & 9.61 & 35.53 \\
\hline CL7 & 449 & $12.04^{\mathrm{a}}$ & 3.63 & 0.75 & 26.13 & 30.17 \\
\hline CL14 & 459 & $10.69^{b}$ & 3.11 & 1.98 & 22.66 & 29.10 \\
\hline CL21 & 451 & $10.70^{\mathrm{b}}$ & 3.29 & 1.13 & 18.23 & 30.77 \\
\hline L7 & 461 & $37.88^{\mathrm{a}}$ & 3.13 & 26.70 & 49.81 & 8.27 \\
\hline L14 & 465 & $37.84^{\mathrm{a}}$ & 3.72 & 25.48 & 48.52 & 9.83 \\
\hline L21 & 462 & $38.69^{\mathrm{b}}$ & 3.19 & 28.98 & 48.82 & 8.25 \\
\hline a7 & 462 & $15.83^{\mathrm{a}}$ & 1.77 & 10.79 & 20.26 & 11.19 \\
\hline a14 & 464 & $16.38^{\mathrm{b}}$ & 2.24 & 8.27 & 21.18 & 13.67 \\
\hline a21 & 463 & $16.69^{\circ}$ & 1.62 & 11.78 & 20.72 & 9.56 \\
\hline b7 & 461 & $13.38^{\mathrm{a}}$ & 1.95 & 8.03 & 17.43 & 14.54 \\
\hline b14 & 465 & $13.69^{b}$ & 2.72 & 4.79 & 19.75 & 19.90 \\
\hline $\mathrm{b} 21$ & 463 & $14.58^{\mathrm{c}}$ & 1.91 & 8.04 & 18.55 & 13.07 \\
\hline
\end{tabular}
frozen meat samples, which increases cooking loss due to the breakdown of membranes.

Mean values followed by different superscript letters, in the same trait, showed difference by the Tukey test with a significance level of 5\%. $\mathrm{N}=$ sample size; $\mathrm{SD}=$ standard deviation; $\mathrm{CV}=$ coefficient of variation. $\mathrm{DL}=$ drip loss; $\mathrm{CL}=$ cooking loss; $\mathrm{L}=$ luminosity; $\mathrm{a}=$ red intensity; $\mathrm{b}=$ yellow intensity. 
The color traits $L^{*}, a^{*}$ and $b^{*}$ showed a tendency to rise over the course of the aging process. The values of $L^{*}$ were similar to those obtained by Chambaz et al. (2003) for Simmental (37.3) and Angus (40.0). Between the 7th and 14th days no difference $(\mathrm{P}>0.05)$ was detected, but mean values found for those times were lower than those at the 21 st day of aging. Higher values of $L^{*}$ were observed in the brightest meat, therefore, our samples were darker at the 7 th and 14 th days than at the 21 st day of aging. Red intensity $\left(a^{*}\right)$ values were similar to those described by Chambaz et al. (2003) in Angus and Charolais (14.2), Simmental (14.3) and Limousin (14.7) cattle. On the other hand, the yellow intensity was higher than the 4.1 and 4.9 found by Chambaz et al. (2003).

According to Viljoen et al. (2002), the $\mathrm{pH}$ obtained $24 \mathrm{~h}$ after slaughter must be lower than 5.8, because a $\mathrm{pH}>5.8$ is common in DFD (dark, firm and dry) meat. So, the mean value for $\mathrm{pH}$ in the present study is slightly above the pattern (Table 1).

\section{Gene and genotypic frequencies}

In the present study, all possible genotypic classes of the markers were observed (Table 2). However, for the E2FB and T945M markers the T/T genotype was observed in only three and two bulls, respectively. This low frequency is a problem for the estimation of the additive effect, because this effect depends on the mean values of both homozygotes, and the mean value of T/T has low accuracy. The high frequency of heterozygotes allows for improvement of Nellore cattle, because gene frequency of both alleles is reasonable for all markers (Table 2).

\begin{tabular}{|c|c|c|c|c|c|}
\hline Molecular markers & Genotypic class & Sample size & Genotypic frequency $(\%)$ & Alleles & Gene frequency $(\%)$ \\
\hline \multirow[t]{3}{*}{ CAPN4751 } & $\mathrm{T} / \mathrm{T}$ & 428 & 67.51 & $\mathrm{~T}$ & 82.18 \\
\hline & $\mathrm{C} / \mathrm{T}$ & 186 & 29.34 & $\mathrm{C}$ & 17.82 \\
\hline & $\mathrm{C} / \mathrm{C}$ & 20 & 3.15 & & \\
\hline \multirow[t]{3}{*}{ GHR2 } & $\mathrm{G} / \mathrm{G}$ & 461 & 72.37 & G & 85.09 \\
\hline & $\mathrm{G} / \mathrm{A}$ & 162 & 25.43 & A & 14.91 \\
\hline & $\mathrm{A} / \mathrm{A}$ & 14 & 2.20 & & \\
\hline \multirow[t]{3}{*}{ T945M } & $\mathrm{C} / \mathrm{C}$ & 488 & 79.22 & $\mathrm{C}$ & 89.37 \\
\hline & $\mathrm{C} / \mathrm{T}$ & 125 & 20.29 & $\mathrm{~T}$ & 10.63 \\
\hline & $\mathrm{T} / \mathrm{T}$ & 3 & 0.49 & & \\
\hline \multirow{3}{*}{$\mathrm{E} 2 \mathrm{FB}$} & $\mathrm{C} / \mathrm{C}$ & 554 & 86.83 & $\mathrm{C}$ & 93.26 \\
\hline & $\mathrm{C} / \mathrm{T}$ & 82 & 12.85 & $\mathrm{~T}$ & 6.74 \\
\hline & $\mathrm{T} / \mathrm{T}$ & 2 & 0.31 & & \\
\hline
\end{tabular}

\section{Association analysis}

GHR2 was not associated with any trait in the present study. Ferraz et al. (2009) found that the G/G genotype of GHR2 improves hot carcass weight. For this reason, the high frequency of the $\mathrm{G}$ allele is easily explained, since the Nellore cattle selection has always focused on increased weight, placing less importance on meat quality. Equally, the T945M has no additive or dominance effects on the traits studied. Ferraz et al. (2009) reported that the C allele of this marker was favorable for increasing the longissimus muscle area in Nellore. Therefore, the color or the water-holding capacity should not be changed when the selection program is using either GHR2 or T945M information.

E2FB is a mutation that is present on chromosome 4, base 3, in exon 2 of the leptin gene. Leptin is a hormone produced by adipose tissue that acts on metabolism and appetite 
control. Therefore, polymorphisms in this gene or on its receptor gene are being studied to identify associations with economically important traits in cattle, as mentioned in Liefers et al. (2005). The E2FB mutation is a substitution of C for T, which in the present study was associated with drip loss at the 7 th day of aging (Table 3). The T/T and T/C genotypes were responsible for more losses than the $\mathrm{C} / \mathrm{C}$ genotype (Table 4) and the $\mathrm{T}$ allele is dominant. Therefore, the selection using E2FB information when directed to the T allele tends to increase drip loss.

\begin{tabular}{lllrrrc}
\multicolumn{6}{l}{ Table 3. Significant association of the traits with molecular markers studied. } \\
\hline Trait & Molecular markers & Type & Effect \pm SE & LRT & P & $\%$ \\
\hline a7 & CAPN4751 & A & $0.3225 \pm 0.1353$ & 5.64 & 0.0175 & 0.99 \\
& & D & $-0.3823 \pm 0.1625$ & 5.50 & 0.0190 & 0.96 \\
a14 & CAPN4751 & A & $0.4054 \pm 0.1562$ & 6.68 & 0.0097 & 2.10 \\
& & D & $-0.4817 \pm 0.1871$ & 6.58 & 0.0103 & 2.08 \\
a21 & CAPN4751 & A & $0.4718 \pm 0.1231$ & 14.45 & 0.0001 & 3.59 \\
& & D & $-0.6012 \pm 0.1483$ & 16.14 & 0.00006 & 3.95 \\
b7 & CAPN4751 & A & $0.2990 \pm 0.1464$ & 4.15 & 0.0416 & 1.51 \\
& & D & $-0.4258 \pm 0.1754$ & 5.85 & 0.0156 & 1.87 \\
b14 & CAPN4751 & A & $0.3842 \pm 0.1800$ & 4.53 & 0.0332 & 1.57 \\
& & D & $-0.5375 \pm 0.2149$ & 6.21 & 0.0127 & 2.94 \\
b21 & CAPN4751 & A & $0.4416 \pm 0.1407$ & 9.54 & 0.0018 & 3.39 \\
& & D & $-0.6276 \pm 0.1691$ & 13.57 & 0.0002 & 3.83 \\
DL7 & E2FB & A & $0.3949 \pm 0.1317$ & 8.90 & 0.0029 & 4.18 \\
\hline
\end{tabular}

$\mathrm{A}=$ additive effect $\mathrm{D}=$ dominance effect $\mathrm{SE}=$ standard error; $\mathrm{LRT}=$ likelihood ratio test; $\mathrm{P}=$ nominal probability value of LRT; $\%=$ variance percentage explained by SNP; $a=$ red intensity; $b=$ yellow intensity; DL = drip loss.

\begin{tabular}{|c|c|c|c|}
\hline \multirow[t]{2}{*}{ Trait } & \multirow[t]{2}{*}{$\mathrm{T} / \mathrm{T}$} & \multicolumn{2}{|c|}{ CAPN4751 } \\
\hline & & $\mathrm{T} / \mathrm{C}$ & $\mathrm{C} / \mathrm{C}$ \\
\hline a7 & $15.98^{\mathrm{b}}$ & $15.62^{\mathrm{a}}$ & $15.47^{\mathrm{a}}$ \\
\hline a14 & $16.53^{b}$ & $16.00^{\mathrm{a}}$ & $15.77^{\mathrm{a}}$ \\
\hline a21 & $17.19^{b}$ & $16.62^{\mathrm{a}}$ & $16.70^{\mathrm{a}}$ \\
\hline b7 & $13.53^{b}$ & $13.11^{\mathrm{a}}$ & $13.12^{\mathrm{a}}$ \\
\hline b14 & $13.82^{\mathrm{b}}$ & $13.20^{\mathrm{a}}$ & $13.09^{\mathrm{a}}$ \\
\hline $\mathrm{b} 21$ & $14.74^{\mathrm{b}}$ & $14.18^{\mathrm{a}}$ & $14.17^{\mathrm{a}}$ \\
\hline \multirow[t]{2}{*}{ Trait } & $\mathrm{T} / \mathrm{T}$ & \multicolumn{2}{|c|}{ E2FB } \\
\hline & & $\mathrm{T} / \mathrm{C}$ & $\mathrm{C} / \mathrm{C}$ \\
\hline DL7 & $4.30^{\mathrm{b}}$ & $4.52^{\mathrm{b}}$ & $2.95^{\mathrm{a}}$ \\
\hline
\end{tabular}

Mean values followed by different superscript letters, in the same line, showed a significance level of $5 \%$ by the Tukey test. $\mathrm{a}=$ red intensity; $\mathrm{b}=$ yellow intensity; $\mathrm{DL}=$ drip loss.

The variance percentage explained by E2FB qualifies it as a good marker for the selection process, especially for reduce drip loss. However, the leptin gene has high influence on metabolism, thus there is a strong possibility that this mutation is also associated with other economically important traits (pleiotropic effect). Therefore, further studies with other animals, carcasses and performance traits must be conducted to obtain more information on this marker and reduce risk of error in selection programs.

Calpain is a protease responsible for postmortem proteolysis of muscle fibers. It has been associated with meat tenderness in Bos taurus, Bos indicus and their crossbreed as reported by White et al. (2005) and here showed a dominance effect on $L^{*}$ at 14 days (L*14). 
This dominance effect helps to explain the variance of this trait; however, it does not carry major implications for breeding purposes, since it depends on an allelic combination at this locus, which is a random event in the course of meiosis. However, CAPN4751 has an additive effect on $a^{*}$ and $b^{*}$ at 7, 14 and 21 days of aging, besides the dominance effect (Table 3). The differences between the means of genotypes T/T and $\mathrm{C} / \mathrm{C}$ for $a^{*} 7, a^{*} 14, a^{*} 21, b^{*} 7, b^{*} 14$ and $b * 21$ indicate that the T/T genotype increases red and yellow intensities, but the $\mathrm{C}$ allele is dominant on the $\mathrm{T}$ allele, as can be observed in Table 4 . The additive effect of this marker increases over the course of the aging process (Table 3), and it was significant at the 7th and 14th days and highly significant at the 21 st day. The $\mathrm{T}$ allele favors an increase in red and yellow meat color, but it is not benign to meat tenderness in Nellore as observed by Pinto et al. (2010). Thus, information on CAPN4751 must be used very carefully.

The associations found in the present research were only statistical, but they explained phenotypic variance between 0.96 and $4.18 \%$ (Table 3 ). However, these associations do not explain the biological mechanism for link phenotypes and genes. The elucidation of the biological mechanism is especially important for the marker E2FB, because it is placed in the leptin gene, which is important to metabolic function. Thus, the marker may have pleiotropic effects on many other economically important traits.

\section{CONCLUSION}

The marker on the CAPN1 gene (CAPN4751) has additive and dominant effects on red and yellow intensities of the meat of Nellore cattle with 7, 14 and 21 days of postmortem aging, and the $\mathrm{T}$ allele increases these intensities.

The marker on the leptin gene (E2FB) has additive and dominant effects on drip losses at the 7th day of postmortem aging, but the genotype T/T was observed in only two animals. Thus, the additive value, for this marker, may have been poorly estimated.

\section{ACKNOWLEDGMENTS}

The authors thank FAPESP for a postdoctoral scholarship (\#07/50736-2), FUNPEC/ RP for financial support for data collection, Agro-Pecuária CFM Ltda. for the phenotype collection, and Merial Saúde Animal/Igenity for genotyping animals.

\section{REFERENCES}

AMSA (1995). Research Guidelines for Cookery, Sensory Evaluation, and Instrumental Tenderness Measurements of Fresh Meat. American Meat Science Association, Chicago.

Buchanan FC, Fitzsimmons CJ, Van Kessel AG, Thue TD, et al. (2002). Association of a missense mutation in the bovine leptin gene with carcass fat content and leptin mRNA levels. Genet. Sel. Evol. 34: 105-116.

Chambaz A, Scheeder MRL, Kreuzer M and Dufey PA (2003). Meat quality of Angus, Simmental, Charolais and Limousin steers compared at the same intramuscular fat content. Meat Sci. 63: 491-500.

Ferraz JB, Pinto LF, Meirelles FV, Eler JP, et al. (2009). Association of single nucleotide polymorphisms with carcass traits in Nellore cattle. Genet. Mol. Res. 8: 1360-1366.

Huff-Lonergan E and Lonergan SM (2005). Mechanisms of water-holding capacity of meat: the role of postmortem biochemical and structural changes. Meat Sci. 71: 194-204.

Liefers SC, Veerkamp RF, Te Pas MF, Delavaud C, et al. (2005). Leptin promoter mutations affect leptin levels and performance traits in dairy cows. Anim. Genet. 36: 111-118. 
Mancini RA and Hunt MC (2005). Current research in meat color. Meat Sci. 71: 100-121.

Pérez-Enciso M and Misztal I (2004). Qxpak: a versatile mixed model application for genetical genomics and QTL analyses. Bioinformatics 20: 2792-2798.

Pinto LF, Ferraz JB, Meirelles FV, Eler JP, et al. (2010). Association of SNPs on CAPN1 and CAST genes with tenderness in Nellore cattle. Genet. Mol. Res. 9: 1431-1442.

Reardon W, Mullen AM, Sweeney T and Hamill RM (2010). Association of polymorphisms in candidate genes with colour, water-holding capacity, and composition traits in bovine $\mathrm{m}$. longissimus and $\mathrm{m}$. semimembranosus. Meat Sci. 86: 270-275.

SAS (2004). SAS/STAT User's Guide: Version 9.1. SAS Institute, Cary.

Viljoen HF, De Kock HL and Webb EC (2002). Consumer acceptability of dark, firm and dry (DFD) and normal pH beef steaks. Meat Sci. 61: 181-185.

White SN, Casas E, Wheeler TL, Shackelford SD, et al. (2005). A new single nucleotide polymorphism in CAPN1 extends the current tenderness marker test to include cattle of Bos indicus, Bos taurus, and crossbred descent. J. Anim. Sci. 83: 2001-2008 